\title{
No Evidence of Human Polyomavirus 9, WU and KI DNA in Kidney and Urinary Bladder Tumour Tissue Samples
}

\author{
Eszter Csoma ${ }^{a}$ László Bidiga ${ }^{b}$ Gábor Méhes ${ }^{b}$ Lajos Gergely ${ }^{a}$ \\ ${ }^{a}$ Department of Medical Microbiology, Faculty of Medicine, and ${ }^{b}$ Department of Pathology, University of \\ Debrecen, Debrecen, Hungary
}

\section{Key Words}

Polyomavirus $\cdot \mathrm{KI}$ polyomavirus $\cdot$ WU polyomavirus $\cdot$ Human polyomavirus 9 . Urinary tract $\cdot$ Tumour

\begin{abstract}
Background/Aims: The oncogenic potential of human polyomaviruses (HPyVs) has been proposed, but so far only Merkel cell carcinoma polyomavirus seems to be associated with a human tumour. The role of BK polyomavirus (BKPyV) in human tumourigenesis remains controversial. BKPyV establishes persistent infection in the urinary tract, and renal and bladder neoplasms have been studied extensively, but conflicting prevalence data are reported. KI, WU and HPyV9 were detected in urine samples suggesting that these viruses may also infect the urinary tract, but their presence in urinary tract tumours has not been studied. The aim of this work was to examine the prevalence of KIPyV, WUPyV, HPyV9 and BKPyV by PCR in renal and bladder neoplasms. Methods: A total of 190 formalin-fixed paraffin-embedded renal neoplasms, bladder cancer and kidney biopsy samples were analysed for the presence of BKPyV, KIPyV, WUPyV and HPyV9 DNA by real-time and nested PCR. Results: Amplifiable DNA was extracted from all the samples, but none of the studied
\end{abstract}

viruses were detected in benign renal neoplasia (0/23), malignant renal tumours (0/89) or bladder cancer (0/76). Conclusion: Our study did not find any evidence that BKPyV, KIPyV, WUPyV or HPyV9 are associated with bladder and renal tumours.

(c) 2016 S. Karger AG, Basel

\section{Introduction}

As all known human pathogenic viruses of the Polyomaviridae family encode early regulatory tumour antigens, the potential oncogenic role of these viruses has been suggested [1-4] since the discovery of the first human polyomavirus ( $\mathrm{HPyV}), \mathrm{BK}$ polyomavirus (BKPyV) [5]. This suggestion was strengthened by in vitro and animal experiments with BKPyV that proved its transforming ability as reviewed previously $[1,3,6]$. After the primary infection, BKPyV establishes a lifelong persistent infection in the urinary tract and renal cells [2], hence there exist large number of studies of urinary tract neoplasia and cancers [7-15]. DNA, RNA or even proteins of the $\mathrm{BK}$ virus have been detected in different human tumours (brain, neuroblastoma, osteosarcoma, bladder,

\section{KARGER}

E-Mail karger@karger.com

www.karger.com/pat
(C) 2016 S. Karger AG, Basel

$1015-2008 / 16 / 0835-0252 \$ 39.50 / 0$ 
Table 1. Patient and tissue sample data

\begin{tabular}{lcccc}
\hline Tissue samples & $\begin{array}{l}\text { Patients/samples, } \\
\mathrm{n}\end{array}$ & $\begin{array}{l}\text { Female, } \\
\mathrm{n}\end{array}$ & $\begin{array}{l}\text { Male, } \\
\mathrm{n}\end{array}$ & $\begin{array}{l}\text { Min.-max. age of patients } \\
\text { (median), years }\end{array}$ \\
\hline Renal neoplasia & $5 / 5$ & 3 & 2 & $6-80.7(64.3)$ \\
Renal adenoma & $10 / 10$ & 9 & 1 & $36.3-64.3(58.7)$ \\
Renal angiomyolipoma & $8 / 8$ & 3 & 5 & $40.5-74.3(62.2)$ \\
Renal oncocytoma & $1 / 1$ & 1 & - & 57.1 \\
Leiomyosarcoma renis & $11 / 11$ & 4 & 7 & $33.7-69.4(58.7)$ \\
Carcinoma renocellulare renis $\quad 5 / 5$ & 3 & 2 & $33.3-83.6(59.5)$ \\
$\quad$ Papillary type & $69 / 71$ & 21 & 48 & $31-81.2(61.7)$ \\
$\quad$ Chromophobe type & & & & \\
$\quad$ Clear cell type & $68 / 76$ & 23 & 45 & $45.3-87.6(68.6)$ \\
\hline Bladder carcinoma & $3 / 3$ & 0 & 3 & $31.9-52.8(37.6)$ \\
Uroepithelial carcinoma & $180 / 190$ & 66 & 114 & $6-87.6(63.5)$ \\
\hline Renal biopsy from renal transplant patients & & & & \\
\hline Total & & & & \\
\hline
\end{tabular}

kidney, adrenal, prostate, genital, colon), but the role of $\mathrm{BKPyV}$ in human cancers is still controversial $[1,4,6$, 16-19].

Although 11 new human pathogenic polyomaviruses (KI, WU, Merkel cell polyomavirus, HPyV6, HPyV7, trichodysplasia spinulosa-associated polyomavirus, HPyV9, HPyV10, STLPyV, HPyV12 and New Jersey polyomavirus) have been discovered since 2007 [20-32], so far only Merkel cell polyomavirus has been associated with a rare, cutaneous tumour. This was named Merkel cell carcinoma as an aetiological agent [33].

$\mathrm{KI}$ and WU polyomaviruses (KIPyV, WUPyV) were first described in 2007 from respiratory samples [20, 21]. Subsequent seroepidemiological studies revealed that both viruses are widespread, the primary infections of which may occur during the early years of life, and adulthood seropositivities are 55-100\% [34-36]. Most of the important questions about the pathogenesis of KIPyV and WUPyV have not been clarified. Their respiratory transmission is suggested based on prevalence data from numerous studies, as has been summarized in review articles [19, 37, 38]. Both KI and WU viruses were detected in urine samples, which suggests that these viruses may also infect the urinary tract [39-41].

HPyV9 was first detected in plasma and urine samples from renal transplant patients [25], following which two teams also found the viral DNA in urine samples $[42,43]$. The pathogenesis and the transmission of HPyV 9 are not known, but it seems to be a frequent infectious agent since seropositivity in adults reaches $47 \%$ and increases with age [44].

No Detection of HPyVs in Bladder and Kidney Tumours
Some publications about the prevalence of KIPyV, WUPyV and HPyV9 in different tumours are available, but these viruses have not been hitherto examined in bladder and renal cancers [45-57]. In the present study the prevalence of KIPyV, WUPyV, HPyV9 and BKPyV were examined by PCR in tissue samples from the urinary tract. In order to reveal a possible association of these viruses with urinary tract tumours, samples from renal and bladder neoplasia were examined.

\section{Materials and Methods}

\section{Patients and Samples}

The Regional and Institutional Ethics Committee of the University of Debrecen approved the study (IX-R-052/00016-29/2012). One hundred and ninety formalin-fixed paraffin-embedded tissue samples were analysed. The samples were submitted for routine diagnosis to the Department of Pathology, University of Debrecen, between 2010 and 2014. Data relating to the number of kidney biopsies (from renal transplant patients), and benign and malignant renal and urinary bladder tumour samples of 180 patients are summarized in table 1 . Ten-micrometre-thick tissue sections were deparaffinised with xylene, then nucleic acid was isolated using the High Pure FFPET DNA Isolation Kit (Roche, Basel, Switzerland) according to the manufacturer's instructions. The quality and quantity of DNA eluted in $50 \mu$ l was checked with a NanoDrop 2000c Spectrophotometer (Thermo Scientific, Waltham, Mass., USA) and stored at $-20^{\circ} \mathrm{C}$ until use.

Detection of WUPyV, KIPyV, HPyV9 and BKPyV DNA

To confirm the effectiveness of nucleic acid extraction, the presence of amplifiable DNA, $\beta$-globin PCR was used with the primers PCO3 (5'ACACAACTGTGTTCACTAGC3') and PCO4 $\left(5^{\prime}\right.$ CAACTTCATCCACGTTCACC $\left.3^{\prime}\right)$. Five microliters of DNA 
Table 2. Primers and PCR data used to study polyomaviruses

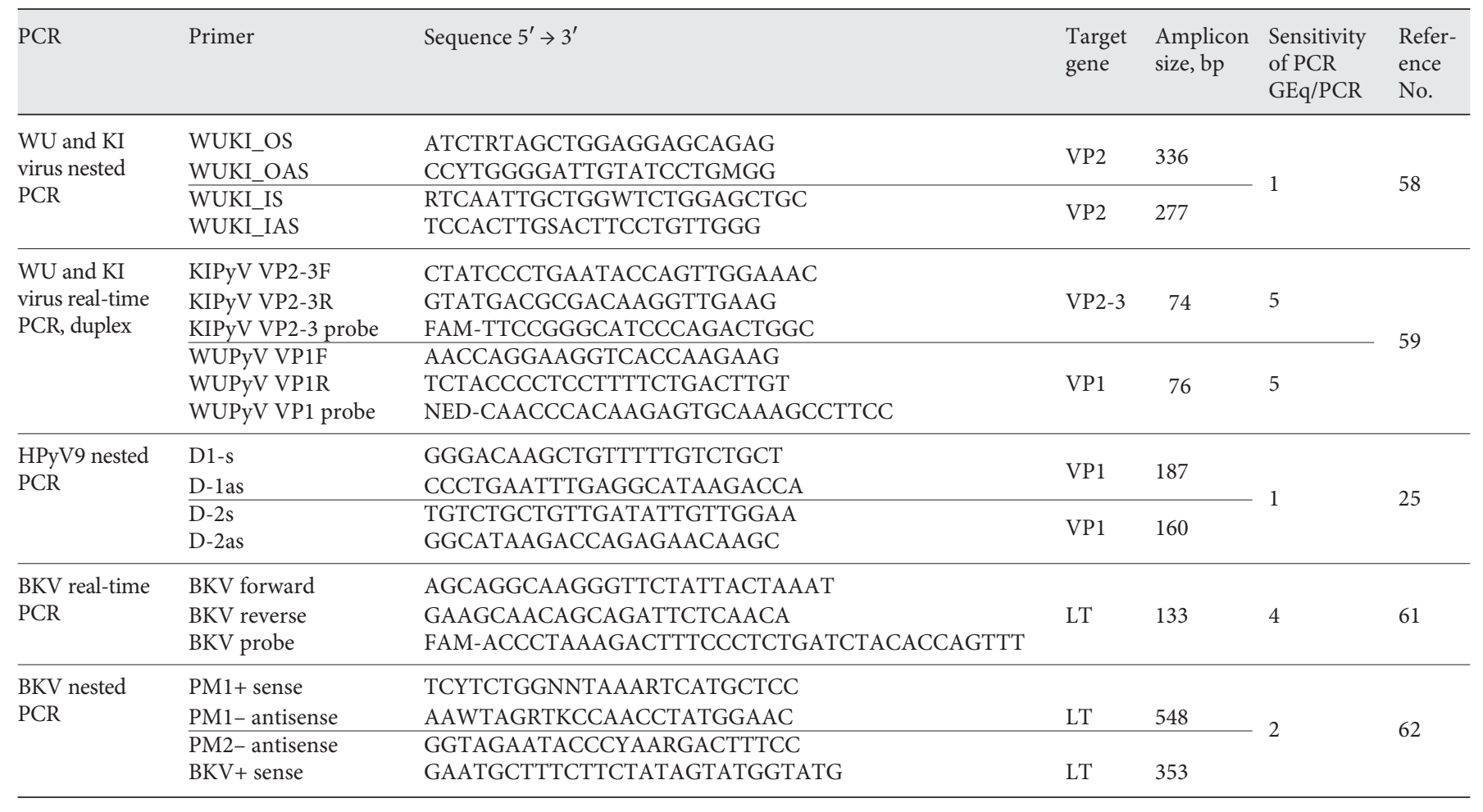

For each real-time assay TaqMan MGB probe was used. VP1 = Viral protein 1 (major capsid protein) coding region; VP2 = viral protein 2 (capsid protein) coding region; VP2-3 = viral protein 2 and 3 (capsid protein) coding region; $\mathrm{LT}=$ large $\mathrm{T}$ antigen coding region; $\mathrm{bp}=\mathrm{base}$ pair; $\mathrm{GEq} / \mathrm{PCR}=$ genome equivalent/PCR.

were amplified in a final volume of $25 \mu$ l containing AmpliTaq Gold 360 Master Mix (Applied Biosystems, Foster City, Calif., USA) and 10 pmol of primers. The annealing temperature was $55^{\circ} \mathrm{C}$. The sequences of the primers and probes along with the data and sensitivities of the PCRs are detailed in table 2.

To detect WU and KI virus DNA, nested and duplex real-time PCRs were carried out with the primers $[58,59]$ and protocols detailed previously $[39,40]$. Plasmids containing the KIPyV and WUPyV genomes were used as positive controls kindly provided by Tobias Allander from Karolinska Institute (Stockholm, Sweden) and David Wang from Washington University (St. Louis, Miss., USA) $[21,60]$. HPyV9 was detected with a nested PCR as detailed previously [42] using primers described by Scuda et al. [25]. Plasmid containing HPyV9 genome kindly provided by Bernhard Ehlers from the Robert Koch Institute (Berlin, Germany) was used as a positive control. Nested PCRs were carried out with $5 \mu \mathrm{l}$ of template DNA in a GeneAmp 9700 PCR system using AmpliTaq Gold 360 Master Mix (Applied Biosystems). The PCR products were visualized by electrophoresis in $1.5 \%$ agarose gel containing ethidium bromide. Real-time PCR with $10 \mu \mathrm{l}$ of template DNA, TaqMan Universal PCR Master Mix and TaqMan probes was performed in an Applied Biosystems 7500 real-time PCR instrument and analysed by 7500 Software v2.0.6 (Applied Biosystems).

$\mathrm{BK}$ virus DNA was checked by real-time PCR according to the protocol detailed previously [61]. A nested PCR was also carried out with previously published primers [62]. Plasmid containing the complete genome of BKPyV Dunlop strain (kindly provided by Serena Delbue from the University of Milan, Italy) was used as a positive control. The first round of $\mathrm{BKPyV}$ nested PCR was performed in a final volume of $20 \mu \mathrm{l}$ containing $5 \mu \mathrm{l}$ of template DNA, $0.4 \mathrm{U}$ of Phusion Green hot start high-fidelity polymerase (Thermo Scientific), $4 \mathrm{nmol}$ dNTPs and 10 pmol of each primer (PM1+ sense and PM1- antisense). For the second round, $2.5 \mu \mathrm{l}$ of PCR product from the first round was amplified in a 25 - $\mu$ l final volume using $0.5 \mathrm{U}$ Phusion Green hot start high-fidelity polymerase, $5 \mathrm{nmol}$ of dNTPs and $10 \mathrm{pmol}$ of each primer (BKV+ sense and PM2 - antisense). The cycling conditions were: $98^{\circ} \mathrm{C}$ for $30 \mathrm{~s}, 30$ cycles: $98^{\circ} \mathrm{C}$ for $10 \mathrm{~s}, 60^{\circ} \mathrm{C}$ for $30 \mathrm{~s}$ ( 1 st round) $/ 55^{\circ} \mathrm{C}$ for $30 \mathrm{~s}(2 \mathrm{nd}$ round), $72^{\circ} \mathrm{C}$ for $30 \mathrm{~s}$ and a final extension at $72^{\circ} \mathrm{C}$ for $5 \mathrm{~min}$.

\section{Results and Discussion}

One hundred and eleven tissue samples from different renal neoplasms (adenomas, angiomyolipomas, oncocytomas, leiomyosarcoma and renocellular carcinomas), 3 kidney biopsy samples and 76 bladder carcinoma tissue samples were studied for the presence of HPyV9, WU, KI and BK. The novel HPyVs were not detected in any of the samples and BKPyV positivity was found in one kidney biopsy 
sample from a renal transplant patient. However, PCRamplifiable DNA was extracted from each tissue sample.

Although the prevalence of KIPyV and WUPyV in different tumours was investigated and published previously by some research teams, with the exception of one study, no association of these viruses and tumours was revealed. In total, 37 and 38 formalin-fixed paraffin-embedded, mucosal melanoma samples [45, 55], 25 freshfrozen, central nervous system tumours, 31 fresh-frozen, neuroblastoma samples [46], 50 neonatal, dried blood spots from children who developed later acute lymphoblastic leukaemia [50], 43 formalin-fixed paraffin-embedded neuroendocrine tumour samples [48], 30 fresh lung adenocarcinomas [49] and 32 neuroendocrine lung tumours [47] were found to be negative for KIPyV and WUPyV DNA by standard [45-47], nested [50], realtime PCR [49] and polyomavirus genotyping assay [48]. Babakir-Mina et al. [63] detected the VP1 region of $\mathrm{KIPyV}$ in 9 out of 40 fresh lung cancer tissue samples, although only 2 malignant tissue samples were positive for the early region of KI virus. These results revealed that the lung can be the site of infection, even if the infected cell type was not identified. In another study, CD68+ cells in lung were found to be positive for the KIPyV antigen, suggesting that alveolar macrophages might be the site of $\mathrm{KIPyV}$ infection [64]. Based on these data it cannot be concluded that KIPyV has any role in oncogenesis.

HPyV9 was examined but not detected in different non-Merkel cell carcinoma skin cancers (paraffin-embedded: 41 basal cell carcinoma, 31 actinic keratosis, 8 in situ squamous cell carcinoma, 52 squamous cell carcinoma, 42 keratoacanthoma, 5 microcystic adnexal carcinoma and 14 atypical fibroxanthoma) [51], 37 mucosal melanoma samples [55], 39 skin and blood samples from patients with cutaneous T-cell lymphoma [54], 31 formalin-fixed paraffin-embedded samples and 8 frozen samples from patients with glioblastoma multiforme [57], and 27 serum samples from patients with chronic lymphocytic leukaemia [52] by real-time PCR. HPyV9 DNA was found by deep sequencing in a skin sample from a patient with Merkel cell carcinoma [53]. Lowquantity HPyV9 DNA was detected in 1 out of the 18 paraffin-embedded melanoma samples examined [56].

The potential role of $\mathrm{BKPyV}$ in the development of bladder, renal and other carcinomas has been reviewed extensively $[1-3,19]$. The virus is ubiquitous with primary infections occurring during childhood, and the seropositivity among adults exceeds $90 \%$. The transmission is suggested to be respiratory, faecal-oral, urinary route, transplacental and even through blood transfu-

No Detection of HPyVs in Bladder and

Kidney Tumours sion and organ transplantation [2]. After the primary infection, lifelong persistence is established, mainly in the urinary tract $[65,66]$. Active, lytic viral replication occurs in $5-10 \%$ of healthy individuals, resulting in virus shedding via urine, but is more frequent in the immunocompromised (such as renal transplant patients) and is in accordance with the rate of the immunosuppression [67, 68]. $\mathrm{BKPyV}$ is able to induce malignant transformation in animals and in in vitro cell cultures, but studies with human cancers are controversial. The presence or absence of BKPyV DNA and/or proteins has been reported, hence the role of this virus in human tumourigenesis is not clarified, as reviewed previously $[1,3,19]$.

In our study, BKPyV DNA was not detected in benign and malignant renal neoplasia $(0 / 111)$ and also not in bladder cancer $(0 / 76)$. Nucleic acid extraction was successful, resulting in a good quantity of amplifiable DNA, and previously used PCR detection methods with good sensitivity levels were used (table 2). In addition, 1 out of the 3 examined renal biopsy samples was BKPyV DNA positive. Antigen expression was not examined.

Based on our data and previous studies, there is no evidence that WUPyV, KIPyV or HPyV9 have any role in oncogenesis; however, this cannot be definitively excluded. Although all three viruses have previously been detected in urine samples, there is no evidence that these viruses infect the urinary tract. Despite the growing number of prevalence data, little or hardly anything is known about the pathogenesis of KIPyV, WUPyV and HPyV9. The cited studies and our new results provide essential data regarding the prevalence of novel HPyVs, but more samples and studies are needed. Identifying the susceptible cells, sites of infection and possible latencies, as well as the isolation of the virions and further in vitro studies are necessary for further progression.

\section{Acknowledgements}

The research presented here was supported by the Hungarian Scientific Research Fund (OTKA-PD109108) and the research activity of Eszter Csoma was supported by the European Union and the State of Hungary, co-financed by the European Social Fund in the framework of the TÁMOP-4.2.4.A/2-11/1-2012-0001 National Excellence Program.

\section{Disclosure Statement}

The authors have no conflicts of interest to disclose. 


\section{References}

1 Abend JR, Jiang M, Imperiale MJ: Bk virus and human cancer: innocent until proven guilty. Semin Cancer Biol 2009;19:252-260.

2 Jiang M, Abend JR, Johnson SF, Imperiale MJ: The role of polyomaviruses in human disease. Virology 2009;384:266-273.

3 zur Hausen H: Novel human polyomaviruses - re-emergence of a well known virus family as possible human carcinogens. Int J Cancer 2008;123:247-250.

4 Harris KF, Chang E, Christensen JB, Imperiale $\mathrm{MJ}$ : $\mathrm{BK}$ virus as a potential co-factor in human cancer. Dev Biol Stand 1998;94:81-91.

5 Gardner SD, Field AM, Coleman DV, Hulme B: New human papovavirus (B.K.) isolated from urine after renal transplantation. Lancet 1971;1:1253-1257.

6 Fioriti D, Videtta M, Mischitelli M, Degener AM, Russo G, Giordano A, Pietropaolo V The human polyomavirus BK: potential role in cancer. J Cell Physiol 2005;204:402-406.

7 Shah KV, Daniel RW, Stone KR, Elliott AY: Investigation of human urogenital tract tumors of papovavirus etiology: brief communication. J Natl Cancer Inst 1978;60:579-582.

8 Grossi MP, Corallini A, Valieri A, Balboni PG, Poli F, Caputo A, Milanesi G, BarbantiBrodano G: Transformation of hamster kidney cells by fragments of BK virus DNA. J Virol 1982;41:319-325.

9 Geetha D, Tong BC, Racusen L, Markowitz JS, Westra WH: Bladder carcinoma in a transplant recipient: evidence to implicate the $\mathrm{BK}$ human polyomavirus as a causal transforming agent. Transplantation 2002;73:19331936.

10 Knoll A, Stoehr R, Jilg W, Hartmann A: Low frequency of human polyomavirus BKV and JCV DNA in urothelial carcinomas of the renal pelvis and renal cell carcinomas. Oncol Rep 2003;10:487-491.

11 Fioriti D, Pietropaolo V, Dal Forno S, Laurenti C, Chiarini F, Degener AM: Urothelial bladder carcinoma and viral infections: different association with human polyomaviruses and papillomaviruses. Int J Immunopathol Pharmacol 2003;16:283-288.

12 Rollison DE, Sexton WJ, Rodriguez AR, Kang LC, Daniel R, Shah KV: Lack of BK virus DNA sequences in most transitional-cell carcinomas of the bladder. Int J Cancer 2007;120: 1248-1251.

13 Roberts IS, Besarani D, Mason P, Turner G, Friend PJ, Newton R: Polyoma virus infection and urothelial carcinoma of the bladder following renal transplantation. Br J Cancer 2008;99:1383-1386.

14 Panagiotakis GI, Papadogianni D, Chatziioannou MN, Lasithiotaki I, Delakas D, Spandidos DA: Association of human herpes, papilloma and polyoma virus families with bladder cancer. Tumour Biol 2013;34:71-79.
15 Bulut Y, Ozdemir E, Ozercan HI, Etem EO, Aker F, Toraman ZA, Seyrek A, Firdolas F: Potential relationship between $\mathrm{BK}$ virus and renal cell carcinoma. J Med Virol 2013;85: 1085-1089.

16 Imperiale $\mathrm{MJ}$ : The human polyomaviruses, BKV and JCV: molecular pathogenesis of acute disease and potential role in cancer. Virology 2000;267:1-7.

17 Croul S, Otte J, Khalili K: Brain tumors and polyomaviruses. J Neurovirol 2003;9:173182.

18 White MK, Khalili K: Polyomaviruses and human cancer: molecular mechanisms underlying patterns of tumorigenesis. Virology 2004;324:1-16.

19 Dalianis T, Hirsch HH: Human polyomaviruses in disease and cancer. Virology 2013; 437:63-72.

20 Allander T, Andreasson K, Gupta S, Bjerkner A, Bogdanovic G, Persson MA, Dalianis T, Ramqvist T, Andersson B: Identification of a third human polyomavirus. J Virol 2007;81: 4130-4136.

21 Gaynor AM, Nissen MD, Whiley DM, Mackay IM, Lambert SB, Wu G, Brennan DC, Storch GA, Sloots TP, Wang D: Identification of a novel polyomavirus from patients with acute respiratory tract infections. PLoS Pathog 2007;3:e64.

22 Feng H, Shuda M, Chang Y, Moore PS: Clonal integration of a polyomavirus in human Merkel cell carcinoma. Science 2008;319: 1096-1100.

23 Schowalter RM, Pastrana DV, Pumphrey KA, Moyer AL, Buck CB: Merkel cell polyomavirus and two previously unknown polyomaviruses are chronically shed from human skin. Cell Host Microbe 2010;7:509-515.

24 van der Meijden E, Janssens RW, Lauber C, Bouwes Bavinck JN, Gorbalenya AE, Feltkamp MC: Discovery of a new human polyomavirus associated with trichodysplasia spinulosa in an immunocompromized patient. PLoS Pathog 2010;6:e1001024.

25 Scuda N, Hofmann J, Calvignac-Spencer S, Ruprecht K, Liman P, Kuhn J, Hengel H, Ehlers B: A novel human polyomavirus closely related to the African green monkey-derived lymphotropic polyomavirus. J Virol 2011;85:4586-4590.

26 Sauvage V, Foulongne V, Cheval J, Ar Gouilh M, Pariente K, Dereure O, Manuguerra JC, Richardson J, Lecuit M, Burguiere A, Caro V, Eloit M: Human polyomavirus related to African green monkey lymphotropic polyomavirus. Emerg Infect Dis 2011;17:1364-1370.

27 Buck CB, Phan GQ, Raiji MT, Murphy PM, McDermott DH, McBride AA: Complete genome sequence of a tenth human polyomavirus. J Virol 2012;86:10887.
28 Siebrasse EA, Reyes A, Lim ES, Zhao G, Mkakosya RS, Manary MJ, Gordon JI, Wang D: Identification of MW polyomavirus, a novel polyomavirus in human stool. J Virol 2012; 86:10321-10326.

29 Yu G, Greninger AL, Isa P, Phan TG, Martinez MA, de la Luz Sanchez M, Contreras JF, SantosPreciado JI, Parsonnet J, Miller S, DeRisi JL, Delwart E, Arias CF, Chiu CY: Discovery of a novel polyomavirus in acute diarrheal samples from children. PLoS One 2012;7:e49449.

30 Lim ES, Reyes A, Antonio M, Saha D, Ikumapayi UN, Adeyemi M, Stine OC, Skelton R, Brennan DC, Mkakosya RS, Manary MJ, Gordon JI, Wang D: Discovery of stl polyomavirus, a polyomavirus of ancestral recombinant origin that encodes a unique $\mathrm{T}$ antigen by alternative splicing. Virology 2013;436:295-303.

31 Korup S, Rietscher J, Calvignac-Spencer S, Trusch F, Hofmann J, Moens U, Sauer I, Voigt S, Schmuck R, Ehlers B: Identification of a novel human polyomavirus in organs of the gastrointestinal tract. PLoS One 2013; 8:e58021.

32 Mishra N, Pereira M, Rhodes RH, An P, Pipas JM, Jain K, Kapoor A, Briese T, Faust PL, Lipkin WI: Identification of a novel polyomavirus in a pancreatic transplant recipient with retinal blindness and vasculitic myopathy. J Infect Dis 2014;210:1595-1599.

33 Coursaget P, Samimi M, Nicol JT, Gardair C, Touze A: Human Merkel cell polyomavirus: virological background and clinical implications. APMIS 2013;121:755-769.

34 Kean JM, Rao S, Wang M, Garcea RL: Seroepidemiology of human polyomaviruses. PLoS Pathog 2009;5:e1000363.

35 Nguyen NL, Le BM, Wang D: Serologic evidence of frequent human infection with WU and KI polyomaviruses. Emerg Infect Dis 2009; 15:1199-1205.

36 Neske F, Prifert C, Scheiner B, Ewald M, Schubert J, Opitz A, Weissbrich B: High prevalence of antibodies against polyomavirus WU, polyomavirus $\mathrm{KI}$, and human bocavirus in German blood donors. BMC Infect Dis 2010;10:215.

37 Babakir-Mina M, Ciccozzi M, Perno CF, Ciotti M: The human polyomaviruses $\mathrm{KI}$ and WU: virological background and clinical implications. APMIS 2013;121:746-754.

38 Babakir-Mina M, Ciccozzi M, Perno CF, Ciotti M: The novel KI, WU, MC polyomaviruses: possible human pathogens? New Microbiol 2011;34:1-8.

39 Csoma E, Meszaros B, Asztalos L, Konya J, Gergely L: Prevalence of WU and KI polyomaviruses in plasma, urine, and respiratory samples from renal transplant patients. J Med Virol 2011;83:1275-1278.

40 Csoma E, Meszaros B, Asztalos L, Gergely L: $\mathrm{WU}$ and $\mathrm{KI}$ polyomaviruses in respiratory, blood and urine samples from renal transplant patients. J Clin Virol 2015;64:28-33. 
41 Motamedi N, Mairhofer H, Nitschko H, Jager G, Koszinowski UH: The polyomaviruses WUPyV and KIPyV: a retrospective quantitative analysis in patients undergoing hematopoietic stem cell transplantation. Virol J 2012; 9:209.

42 Csoma E, Sapy T, Meszaros B, Gergely L: Novel human polyomaviruses in pregnancy: higher prevalence of $\mathrm{BKPyV}$, but no WUPyV, KIPyV and HPyV9. J Clin Virol 2012;55:262265.

43 Siebrasse EA, Bauer I, Holtz LR, Le BM, Lassa-Claxton S, Canter C, Hmiel P, Shenoy S, Sweet S, Turmelle Y, Shepherd R, Wang D: Human polyomaviruses in children undergoing transplantation, United States, 20082010. Emerg Infect Dis 2012;18:1676-1679.

44 Ehlers B, Wieland U: The novel human polyomaviruses HPyV6, 7, 9 and beyond. APMIS 2013;121:783-795.

45 Giraud G, Ramqvist T, Ragnarsson-Olding B, Dalianis T: DNA from BK virus and JC virus and from $\mathrm{KI}, \mathrm{WU}$, and $\mathrm{MC}$ polyomaviruses as well as from simian virus 40 is not detected in non-UV-light-associated primary malignant melanomas of mucous membranes. J Clin Microbiol 2008;46:3595-3598.

46 Giraud G, Ramqvist T, Pastrana DV, Pavot V, Lindau C, Kogner P, Orrego A, Buck CB, Allander T, Holm S, Gustavsson B, Dalianis T: DNA from KI, WU and Merkel cell polyomaviruses is not detected in childhood central nervous system tumours or neuroblastomas. PLoS One 2009;4:e8239.

47 Duncavage EJ, Le BM, Wang D, Pfeifer JD: Merkel cell polyomavirus: a specific marker for Merkel cell carcinoma in histologically similar tumors. Am J Surg Pathol 2009;33: 1771-1777.

48 Schmitt M, Hofler D, Koleganova N, Pawlita M: Human polyomaviruses and other human viruses in neuroendocrine tumors. Cancer Epidemiol Biomarkers Prev 2011;20:15581561.

49 Teramoto S, Kaiho M, Takano Y, Endo R, Kikuta H, Sawa H, Ariga T, Ishiguro N: Detection of KI polyomavirus and WU polyomavirus DNA by real-time polymerase chain reaction in nasopharyngeal swabs and in normal lung and lung adenocarcinoma tissues. Microbiol Immunol 2011;55:525-530.
50 Gustafsson B, Honkaniemi E, Goh S, Giraud G, Forestier E, von Dobeln U, Allander T, Dalianis T, Bogdanovic G: KI, WU, and Merkel cell polyomavirus DNA was not detected in Guthrie cards of children who later developed acute lymphoblastic leukemia. J Pediatr Hematol Oncol 2012;34:364-367.

51 Scola N, Wieland U, Silling S, Altmeyer P, Stucker M, Kreuter A: Prevalence of human polyomaviruses in common and rare types of non-Merkel cell carcinoma skin cancer. Br J Dermatol 2012;167:1315-1320.

52 Imajoh M, Hashida Y, Taniguchi A, Kamioka M, Daibata M: Novel human polyomaviruses, Merkel cell polyomavirus and human polyomavirus 9, in Japanese chronic lymphocytic leukemia cases. J Hematol Oncol 2012;5:25.

53 Foulongne V, Sauvage V, Hebert C, Dereure $\mathrm{O}$, Cheval J, Gouilh MA, Pariente K, Segondy M, Burguiere A, Manuguerra JC, Caro V, Eloit M: Human skin microbiota: high diversity of DNA viruses identified on the human skin by high throughput sequencing. PLoS One 2012;7:e38499.

54 Du-Thanh A, Foulongne V, Guillot B, Dereure O: Recently discovered human polyomaviruses in lesional and non-lesional skin of patients with primary cutaneous T-cell lymphomas. J Dermatol Sci 2013;71:140-142. 55 Ramqvist T, Nordfors C, Dalianis T, Ragnarsson-Olding B: DNA from human polyomaviruses, TSPyV, MWPyV, HPyV6, 7 and 9 was not detected in primary mucosal melanomas. Anticancer Res 2014;34:639-643.

56 Schrama D, Groesser L, Ugurel S, Hafner C, Pastrana DV, Buck CB, Cerroni L, Theiler A, Becker JC: Presence of human polyomavirus 6 in mutation-specific BRAF inhibitor-induced epithelial proliferations. JAMA Dermatol 2014;150:1180-1186.

57 Hashida Y, Taniguchi A, Yawata T, Hosokawa S, Murakami M, Hiroi M, Ueba T, Daibata M: Prevalence of human cytomegalovirus, polyomaviruses, and oncogenic viruses in glioblastoma among Japanese subjects. Infect Agent Cancer 2015; 10:3.

58 Sharp CP, Norja P, Anthony I, Bell JE, Simmonds P: Reactivation and mutation of newly discovered WU, KI, and Merkel cell carcinoma polyomaviruses in immunosuppressed individuals. J Infect Dis 2009;199:398-404.
59 Kuypers J, Campbell AP, Guthrie KA, Wright NL, Englund JA, Corey L, Boeckh M: WU and KI polyomaviruses in respiratory samples from allogeneic hematopoietic cell transplant recipients. Emerg Infect Dis 2012;18:15801588.

60 Lindau C, Tiveljung-Lindell A, Goh S, Ramqvist T, Allander T: A single-tube, realtime PCR assay for detection of the two newly characterized human KI and WU polyomaviruses. J Clin Virol 2009;44:24-26.

61 Dumoulin A, Hirsch HH: Reevaluating and optimizing polyomavirus $\mathrm{BK}$ and JC realtime PCR assays to detect rare sequence polymorphisms. J Clin Microbiol 2011;49:13821388.

62 Fedele CG, Ciardi M, Delia S, Echevarria JM, Tenorio A: Multiplex polymerase chain reaction for the simultaneous detection and typing of polyomavirus JC, BK and SV40 DNA in clinical samples. J Virol Methods 1999;82: 137-144.

63 Babakir-Mina M, Ciccozzi M, Campitelli L, Aquaro S, Lo Coco A, Perno CF, Ciotti M: Identification of the novel KI polyomavirus in paranasal and lung tissues. J Med Virol 2009; 81:558-561.

64 Siebrasse EA, Nguyen NL, Smith C, Simmonds $\mathrm{P}$, Wang D: Immunohistochemical detection of KI polyomavirus in lung and spleen. Virology 2014;468-470C:178-184.

65 Heritage J, Chesters PM, McCance DJ: The persistence of papovavirus BK DNA sequences in normal human renal tissue. J Med Virol 1981;8:143-150.

66 Chesters PM, Heritage J, McCance DJ: Persistence of DNA sequences of BK virus and JC virus in normal human tissues and in diseased tissues. J Infect Dis 1983;147:676-684.

67 Egli A, Infanti L, Dumoulin A, Buser A, Samaridis J, Stebler C, Gosert R, Hirsch HH: Prevalence of polyomavirus BK and JC infection and replication in 400 healthy blood donors. J Infect Dis 2009;199:837-846.

68 Dharnidharka VR, Abdulnour HA, Araya CE: The $\mathrm{BK}$ virus in renal transplant recipients review of pathogenesis, diagnosis, and treatment. Pediatr Nephrol 2011;26:1763-1774. 